\title{
CONGENITAL ANOMALIES OF THE OSSICLES WITHOUT DEFORMITIES OF THE EXTERNAL EAR
}

\section{By}

Yasushi KOIDE, M.D., Isao KATO, M.D., Hisao YAMAZAKI, M.D., Mutsuo SHIINA, M.D., YoIchi TSUCHIDA, M.D. and Tatsuhiko ARAI, M.D.

From the Department of Otolaryngology Niigata University School of Medicine

Anomaly of the ossicles is frequently seen in a patient with congenital anomalies of the head or face, such as congenital obstruction of the external ear canal, Treacher Collins syndrome or cephalopathy. Congenital anomaly of the ossicles however is not a rare occurrence even in a patient without anomalies of the head or face.

Here, we would present our own experience with six cases of congenital anomalies of the ossicles and with one case of congenital deformity of the round window. The patients with anomalies of the ossicles had non-progressive hearing impairment of purely conductive type, except for one case which had been accompanied by otosclerotic changes and had a bone conduction loss.

Case 1. 24-year-old male.

An exploratory operation of the left ear had revealed that there were a bony fusion of the short process of incus with the horizontal semicircular canal and a dislocation of the long process of incus, resulting in separation of the incudostapedial joint. The bony bridge was removed and the separated joint was reconstructed by means of a polyethylene tube strut. The acoustic gain was $42 \mathrm{db}$.

Case 2. 41-year-old male.

Congenital anomaly of the left middle ear was found to be a bony fusion of the short process of incus with the horizontal semicircular canal.
The bony bridge was removed, resulting in a hearing improvement. But his hearing became worse after several months, probably due to recurrence of ankylosis.

Case 3. 21-year-old male (left ear)

Case 4. 24-year-old male (left ear)

Both cases had congenital separation of the incudostapedial joints, due to maldevelopment of the long process of incus. These separated joints were reconstructed by means of a polyethylene tube strut. Hearing improvement were considerable in both cases.

Case 5. 31-year-old male.

Congenital absence of the head and crus of the stapes was found in his left ear. The footplate was movable. A polyethylene tube collumela was introduced between the long process of incus and the foot-plate. Hearing gain was about $30 \mathrm{db}$.

Case 6. 38-year-old female.

The patient had otosclerosis in both ears. Congeaital separation of the incudostapedial joint was seen in the left ear. Following a stapes mobilization operation, the ossicular chain was reconstructed by means of a polyethylene tube strut. Hearing gain was considerable.

Case 7. 25-year-old female (right ear).

The round window niche was remarkably narrow. 


\section{鳥居恵二名举教授喜寿記念論文}

\section{外耳奇形を伴わ好先天性と 思われる伝音機構奇形}

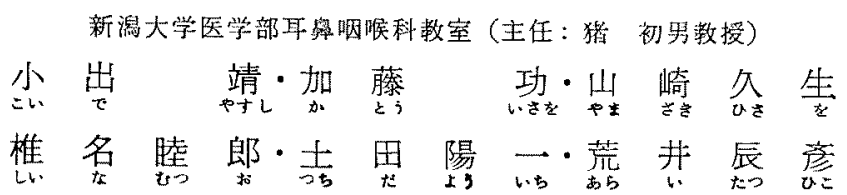

中耳炎や頭部外傷の既往歷がなく，かつ外耳道や鼓膜 所見が正常にもかか⿰力らず，著明な伝音難聴を呈する疾 患が若干知られている．かよらな疾患を大きく2つに分 類すると，その第 1 は幼少時には正常㯖力であつたが， 生長する伴つて進行性の伝音難㯖を抏こす耳硬化症で ある。この智患の伝音難聴の原因は種 々の程度の鐙骨底 板の固着であつて，通常は低音域の気導聴力の損失が著 朋であるが，病変が進行し内耳を侵すに至ると高音域の 気導㯖力の損失も著明となり，骨導域値上昇も見るに至 る.

第2 の疾患は先天性の耳小骨連鎖異常と解されるもの であつて，このものの最も特徽的なことは非進行性の伝 音難㯖といら点にある。年令的には先天性なるが故に奻 小贸にも見出されるるので，耳硬化症が通常は妸小児に 㤝胃され奴ことと全く異つている，聴力像では骨導の 低下がなく，会話音域で 45 60db の平竘気導聴力損 失が見られることが多く，本平型の聴力像がみられる。

耳硬化症と先天性耳小骨連鑜異常の鑑別の鍵は，成人 に䋆いては難㯖が進行性か非進行性かといら点にかかる が，実際に問診しても明確な答が得られないことが多 い. 并れ故に耳硬化症の疑いの下に手術が行われること が多い上らた。

先天性の耳小骨連鎖異常，6つと具体的にいらと耳小 骨奇形をしばしば随伴するものとして，小耳症，外耳道 開鎖应等が周知である，その他に，顔面および頭蓋骨の 発育異常と、眼瞼の特異な变化を主徽とする Treacher -Collins Syndrome (dystosis cranio-facialis)なる疾 患に，しぱしば耳小骨奇形がみられることが報告されて いる122，乙かし，表面的には明膫な奇形が認められぬ のに，手術の途中で先天性耳小骨奇形が見出される場合 る決して稀でなく，本邦ならびに外国においてかょうな 報告が発表されつつある。
私共の手術絽放では先天性耳小骨奇形は従来孝兄られ ている程稀でないょらに感じて扮り，近年の自ら手術し た症例の中に耳小骨奇形を？例と正门笖奇形 1 例を見出

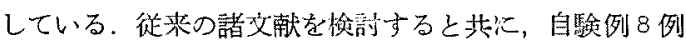
を紹介し若干刀涍察を加えてみたいと思う。

\section{単純性の先天性耳小骨奇形 の文献的考察}

耳小骨を発生学的にみると，耳小骨の原基は第 1 鰓弓 と第 2 鰓亏であつて，前者からは懒骨と砧骨，後者上り は鐙骨が発生すると考えら机ている，従つて耳小骨の全 部が同時に奇形を抗こすよりは，第 1 上第 2 の鰓弓由来 の耳小骨が互に別眖に奇形を抗こす頻度が高いと思われ る.

外耳奇形や Treacher Collins Syndrom 等涟伴し

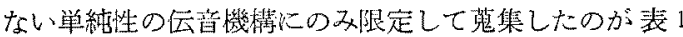
であるが，奇形の実態は実に多種多栐である，奇形のお こるのは鐙骨に最も頻高が高かく，過剩の化骨による鐙

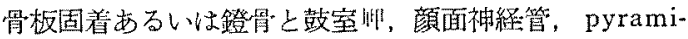
dal eminence 等の間の骨橋形成による镫骨の不動化 と，逆に鐙骨の形成不全に上る奇形る多い。また卵円空 が骨性に閉鎖されている症例の報合もみられる。

鐙骨に関連した奇形の頻度に比べると，桘骨と砧骨に 奇形がおこる頻度はかなり少い，その中で桘骨の著明な 奇形はあまりない上らで，その大部分は砧骨に見られ る。その主なるものは砧鐙閏節の先天性盛断で，その原

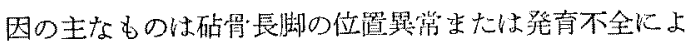
る短小が大部分の原因を占めている，镫骨に見られたよ うな周辺部位との骨性瘾合怗骨にはあまり見られぬ

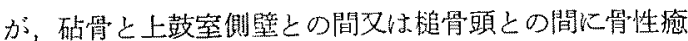
合をみることがある，砧骨長朋と鐙骨頭部との間の丽性

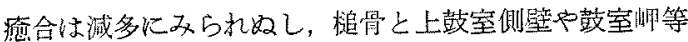
との骨橋形成はまだ報告を見ない。 
表 1 単純性の先天性耳小管奇形の種々

\begin{tabular}{|c|c|}
\hline 交 & 䍿 \\
\hline $\begin{array}{l}\text { Henner }{ }^{3)} \text {, } \\
\text { Henner } \\
\quad \& \\
\text { Buckingham } 4)\end{array}$ & 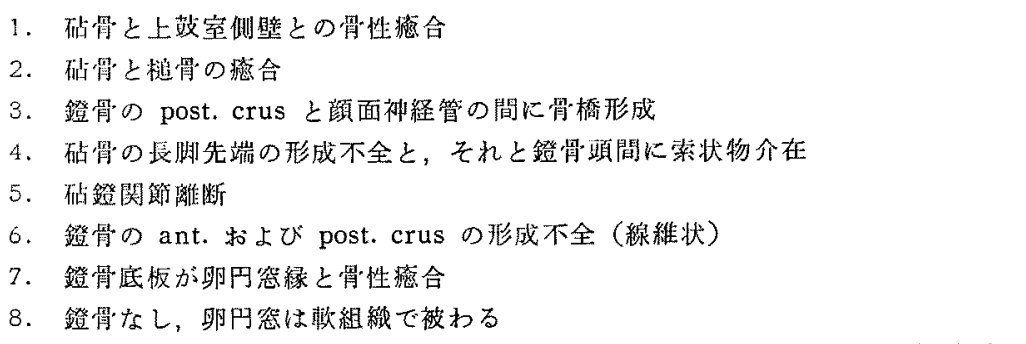 \\
\hline $\begin{array}{l}\text { Tolan } \\
\qquad \& \\
\text { Wilson }\end{array}$ & 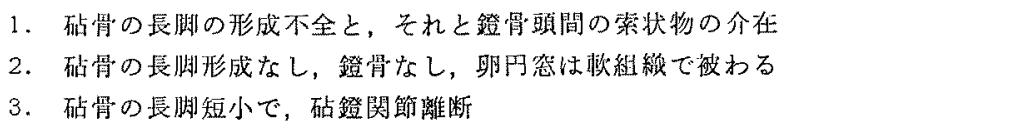 \\
\hline Hough ${ }^{6>8)}$ & 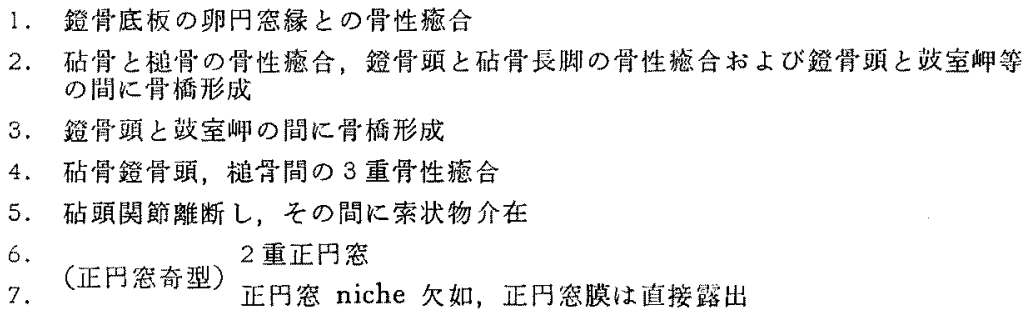 \\
\hline
\end{tabular}

\begin{tabular}{|c|c|}
\hline House 等 7 & 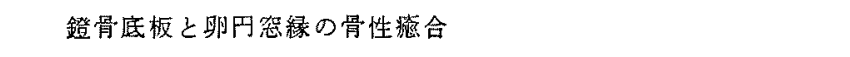 \\
\hline $\begin{array}{l}\text { Schuknecht } \\
\qquad \& \\
\text { Trupiano }\end{array}$ & 鐙骨頭と pyramidal eminence 間の骨橋形成 \\
\hline 高原等 10$)$ & $\begin{array}{l}\text { 1. 梴砧関節䧻断, 鐙骨形成不全で肉芽様 } \\
\text { 2. 鐙骨形成不全, post. crus のみ骨形成し他は肉芽様 }\end{array}$ \\
\hline $\begin{array}{l}\text { Caparosa } \\
\quad \& \\
\text { Klassen } \\
\end{array}$ & $\begin{array}{l}\text { 1. 鐙骨の頭部と crus 形成不全で系状 } \\
\text { 2. 鐙骨の頭部と crus 形成不全で, 系状の single crus }\end{array}$ \\
\hline 中村，山箱落 12) & $\begin{array}{l}\text { 1. 鐙骨底板固着 } \\
\text { 2. 砧骨と鐙骨形成なし（両側性） }\end{array}$ \\
\hline 中村, 山漆 13) & 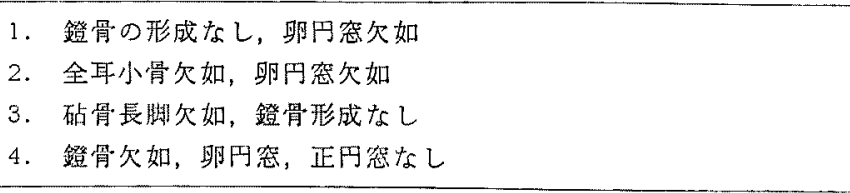 \\
\hline Tabor ${ }^{14)}$ & 鐙骨痕跡的，卵円空なし \\
\hline Pou ${ }^{15)}$ & 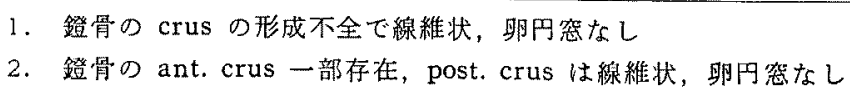 \\
\hline
\end{tabular}




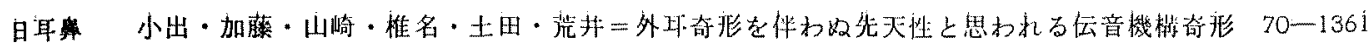

な物円空中正円空の奇形も絶然でなく報告例が若干 ある。すなわち中村と山藤 ${ }^{13)}$, Tabor ${ }^{14)}$, Pou ${ }^{15)}$, Fernandez と Ronis ${ }^{16)}$ は卵円空久如淀例を，中村と 山藤 ${ }^{3)}$ は卯円空と正円空の雨空の闹特欠如症例 t報告 している。

\section{先天性と思われる単純性の}

伝音機䅜奇形の自験例

視骖によつて外耳に何ら異常なく、李た身体の他部位
に奇形又は発育異常を認めない患者で，耳手術の際に先 天性の耳小筲，その他に奇形と判定されたものは自歌例

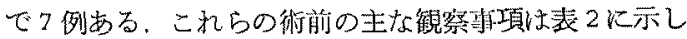
た。

各症例の手術所見と手術成結注以下の如くである。 症例 !(圈 1)。

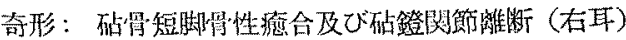
在耳の年術では，乳突部の含気化良炸，鼓室上孚突部

表 2 自験例の衍前主要所見

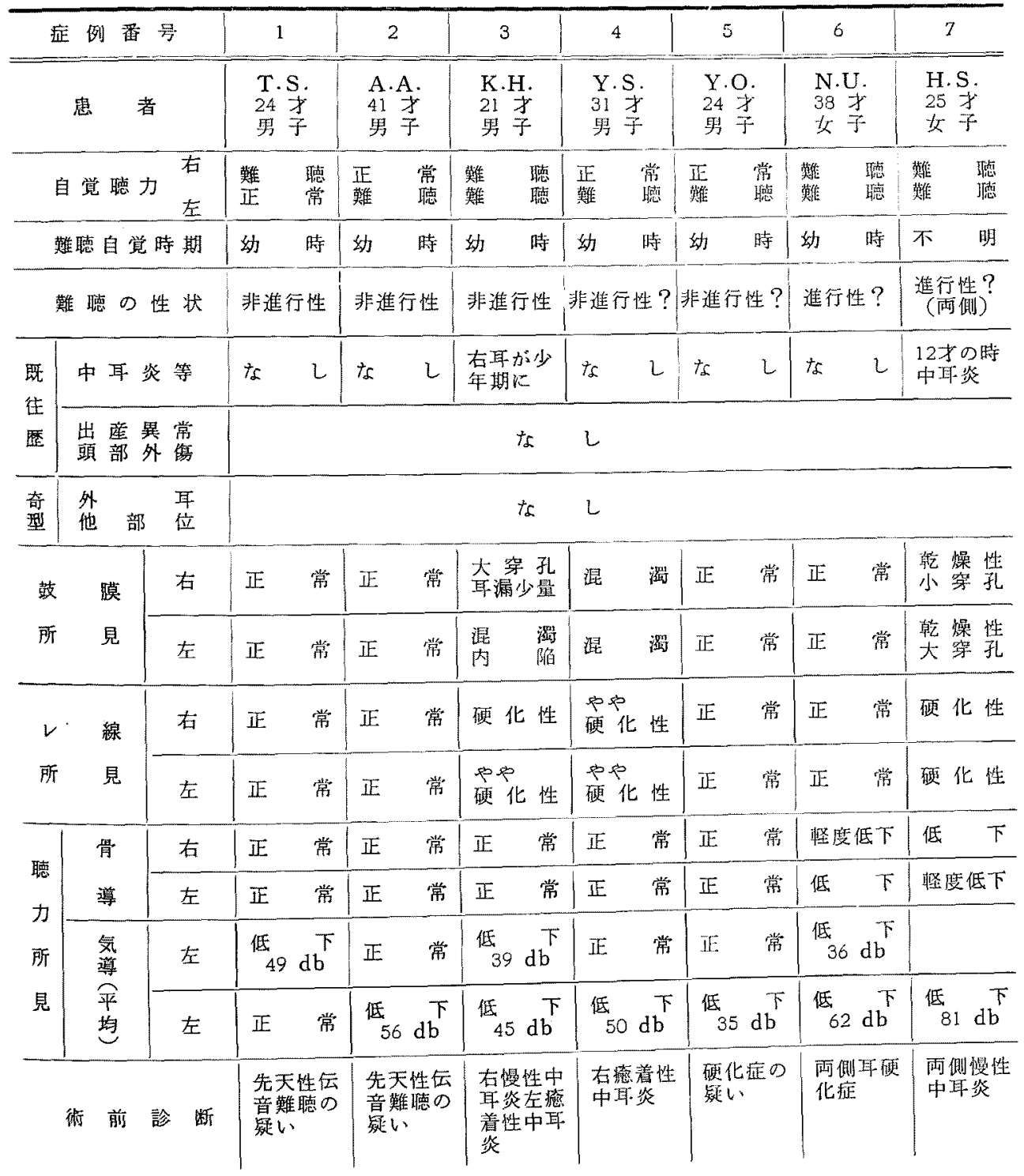


には炎症性の病变全くない，砧骨の短脚怯水平半規管隆

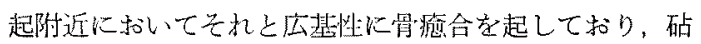
骨は完全に不娅化している。砧骨短脚亚びに水平半規管

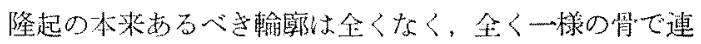
続していた，鐙骨は完全に可動性があるが，砧骨長脚が 買常に前方に枟位しており，そのため砧鐙関節に離断が あり，鐙骨頭と長脚の問に線維状の糸が張つていた。 上の外に異常はない。

まずノで砧骨短脚を削り出し，これが終つてから骨 橋を基部から削除し, 再痹着防止のためこの間に静脈弁 を㨉入した，砧骨長脚と蹬骨の連結はポリエチレン・チ

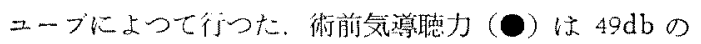

平均損失であつたが，術後 $5 \mathrm{db}(\mathrm{O})$ となり現在迄こ れに近いレベルが保たれている。

症例 2 (図2).

奇形：砧骨短脚骨性癋合 (左耳)

左耳の手術では症例 1 の場合々殆ど同一所見で, 本症 例では砧鐙関節の離断がなかつた点のみが異つている。 砧骨短却の骨性癒合は症例 1 亿比べると厇基性の度合い が軽度であつた。

症例 1 の如くまずミで砧骨短脚をトリミングをし， 次いで骨橋を基部から除去したが症例 1 との比較のため この間に静脈升を㨀入しなからた。術前気尊聴力

は $56 \mathrm{db}$ 平约の椇失で, 術後数力月間 (O) は $34 \mathrm{db}$
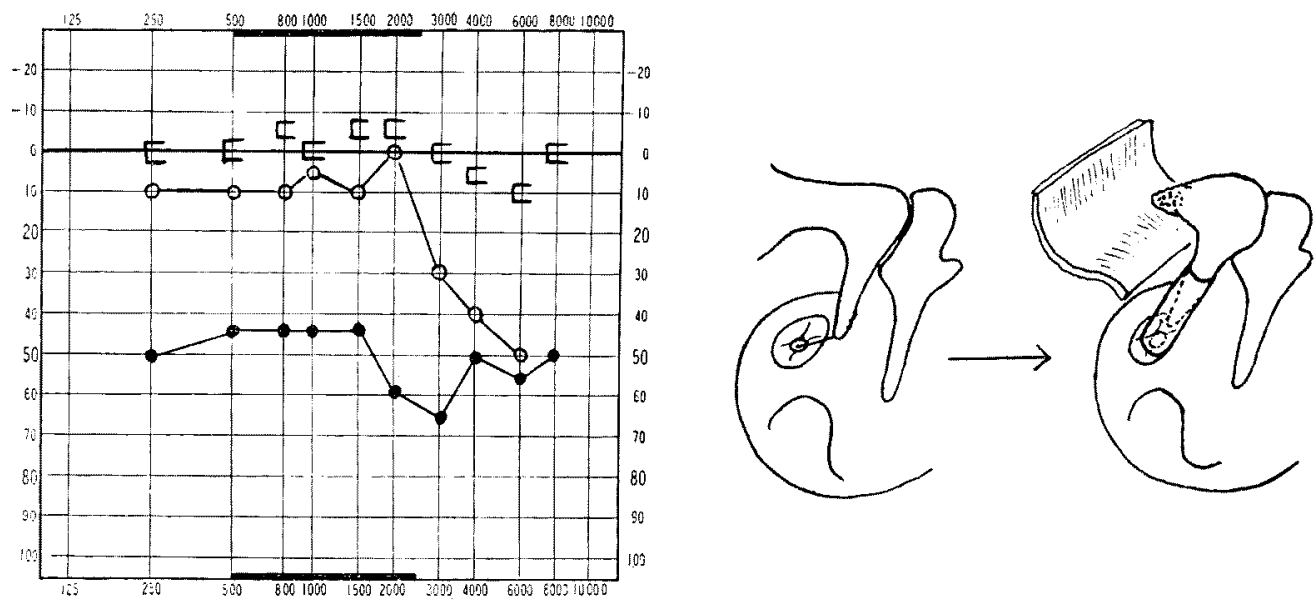

図

2
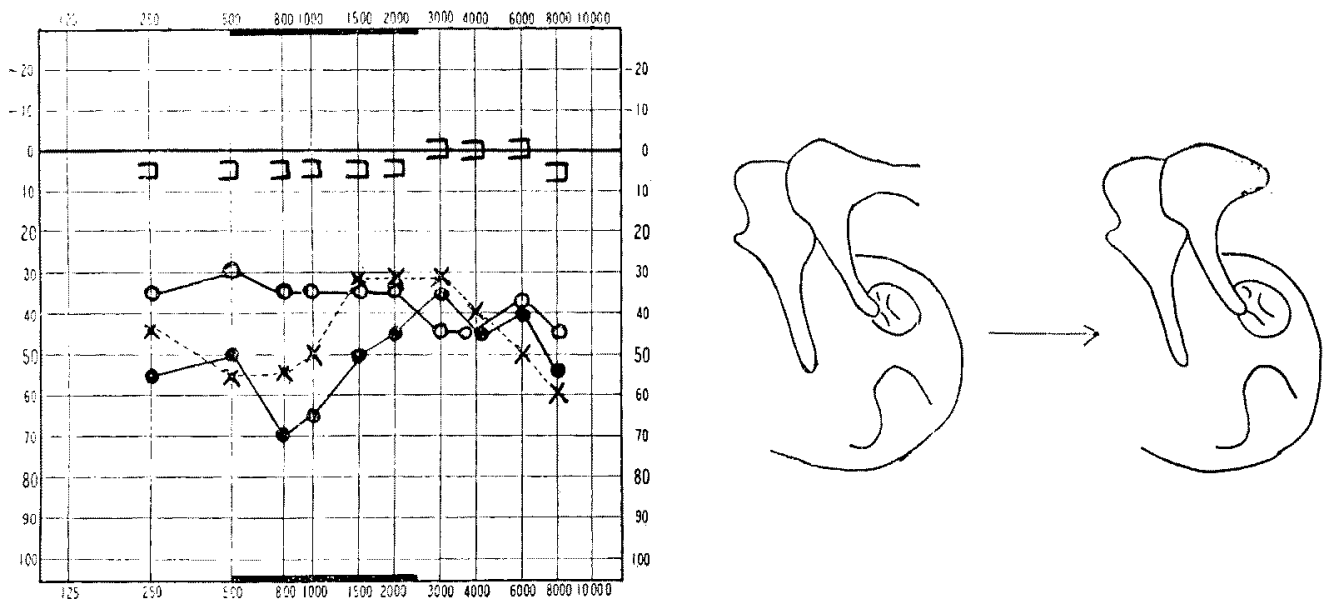


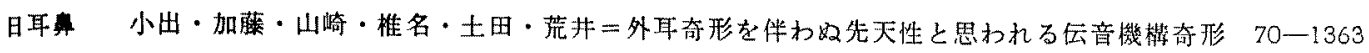

図 3
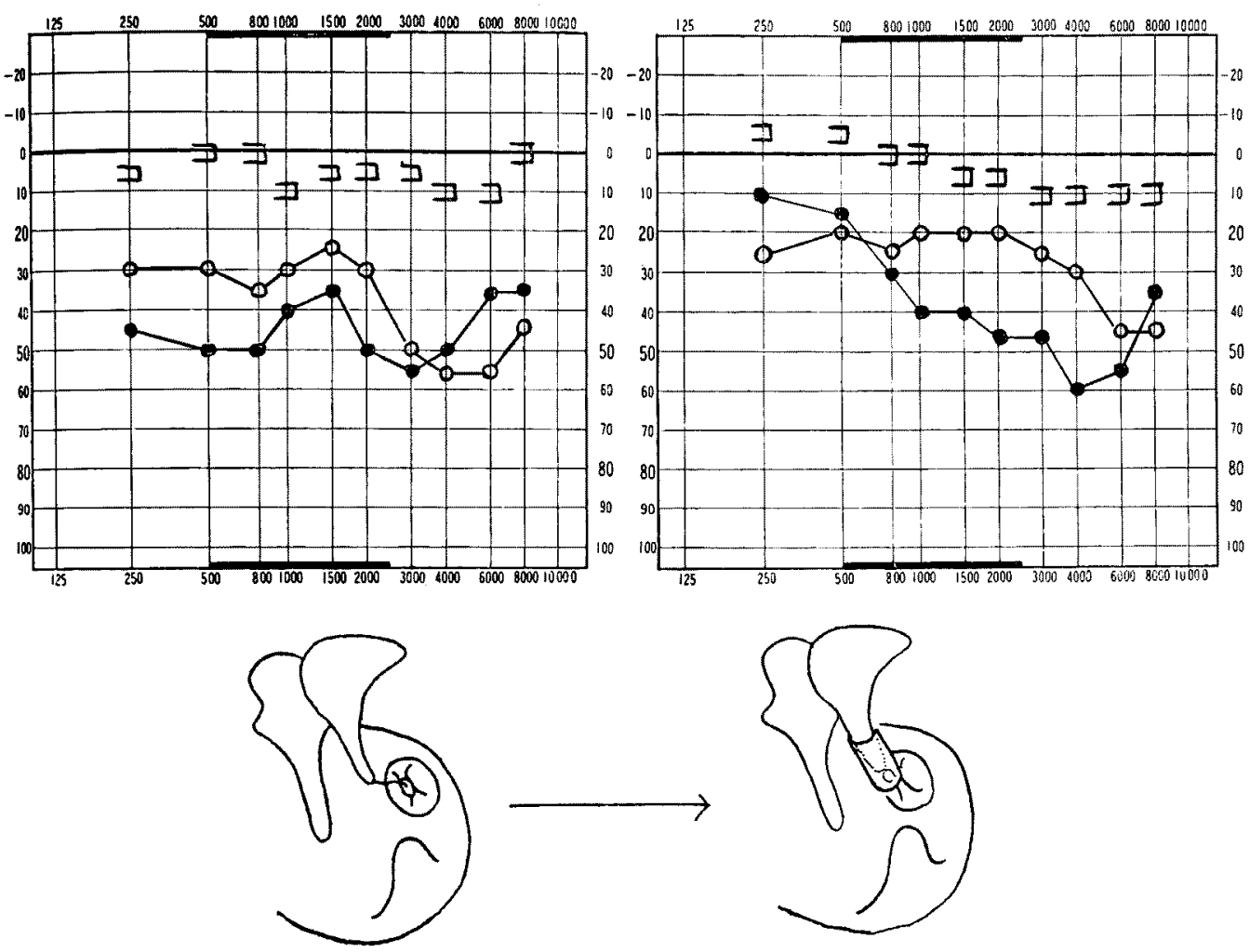

图 4
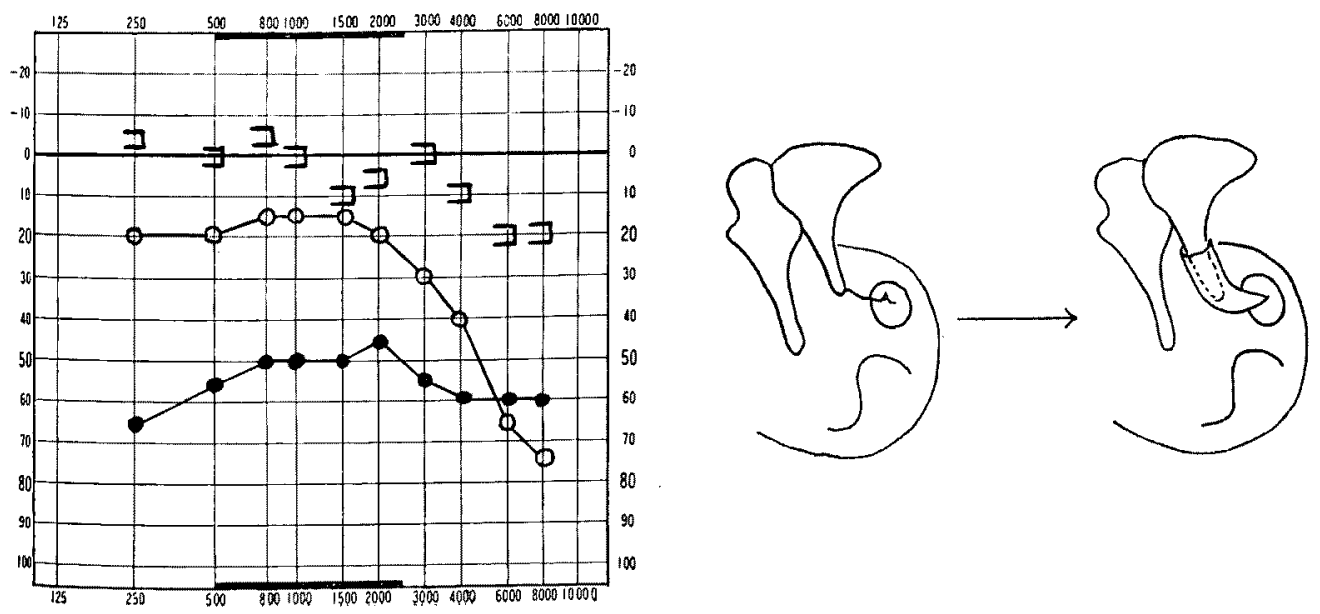


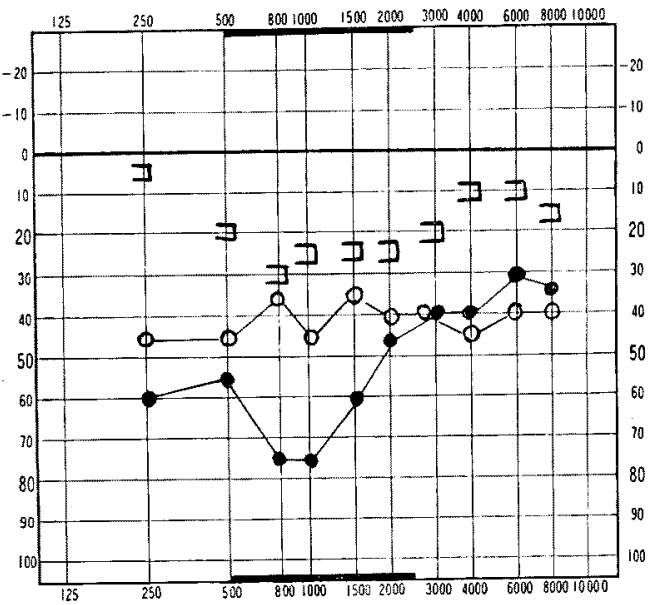

图 6

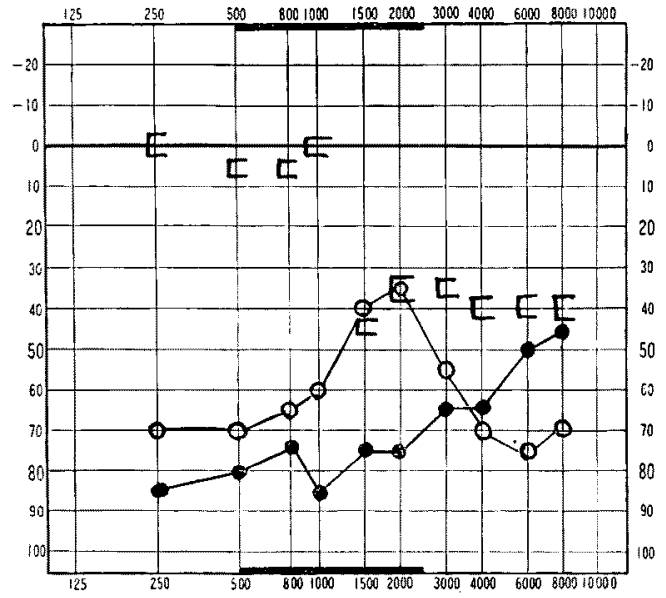

平均であつたが，その後聴力（x） は低下し $48 \mathrm{db}$ と なるに至つた。耳硬化症に机いて単なる蹬骨受斯術を行 つたのでは，早晚再瘾着が执こり聴力の改善は一眭的に 止るといわれているが，これと類似の事情が本症例に拈 こつためのと解される、徒つて症例1に行つたよらな静

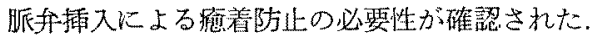

泟例 3 (园 3 の左)

奇形：砧鐙関節離断 (左耳)

左耳の手術所見で豉室叔よび孚突部には炎症等の病

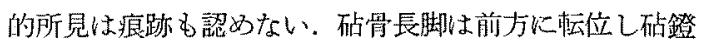
関節の㒕断のみがあり，年の間に索状の線維が存在して いた，鐙骨の可動性悢好であつた。

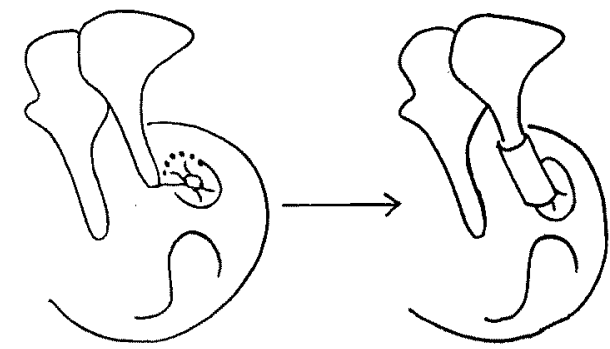

6

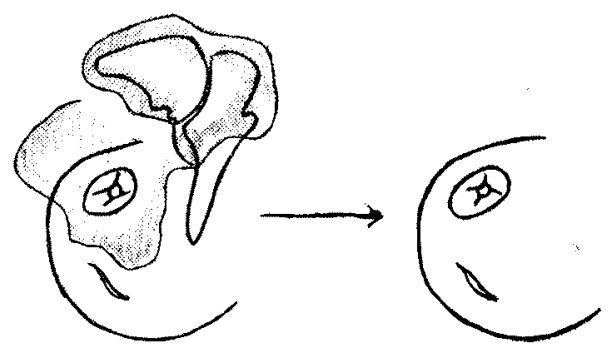

砧鐙閔節離断部をポリエチレン・チュープで連結し た。術前気望撙力（○）は $45 \mathrm{db}$ 平均損失であつたが，

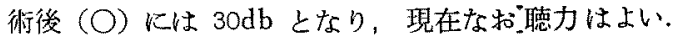
右耳の手術所見ては，病変は典型的な慢性中耳炎で, 耳小骨の非態異常や連鎖離断は全く認めなかつた。

症例 4 (図 4)

奇形：鐙骨の頭頸部及び crus 形成不全 (左耳) 左耳の手術所見では含気化仙比較的良好で，過去に资 症のあつたことを示す所見はない，奇形は鐙骨にあつて 鐙骨底板は存在し可動性良好であつたが，䫓頸部执よび crus は線維様又は肉芽様であつて正常な形態は全くな い，砧骨長脚にポリエチレン・チューブをはめて，その 
先端を鎑骨底板に接ししめた，術前聴力（の）は $50 \mathrm{db}$ の平的損失であつたが，術後聴力 (O) は改善され $20 \mathrm{db}$

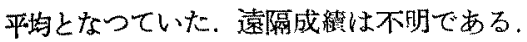

症例 5 (図 3 の右).

奇形：砧鐙関節㒕断（左耳）

所見は症例 3 と殆ど同一なので紐部は省略する，坽断

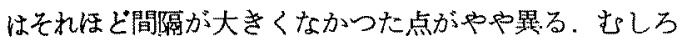
不完全離断に近からた，術前聴力（○）が平汮 $35 \mathrm{db}$ の 損失で，これが術後（O） $20 \mathrm{db}$ に改善されている。遠

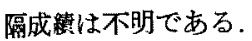

症例 6 (図 5).

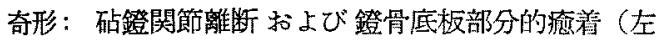
耳)

術前雨側耳硬化症と診断された症例であるが，右耳の 聴力が比較的良好なので左耳のみの手術を行つた，手術 所見では㷋定はその痕跡だにもない，砧骨長脚は正常よ りやや短小で鐙骨との間に索状のものが張られていた。

鐙骨は不動性であるが， anterior crus の附近にのみ骨 癒合があつた、鐙骨底板のその部の輸度が若干不鮮明と なつているが，耳硬化症の発生がこの部に始まることが 多いことから考えると，先天性の奇形より忧しら耳硬 化症そのものと考えた方がよいと思称れる，文献に上る と耳硬化应では骨に vascularity が豊富で血管を見出 しらるとされるが，本庭例では vascularity の特によ いといら印象はなかつた。

手術坆鐙骨受動術とポリエチレン・チユーブに上る連 镍形成を行つた，術前聴力（○）が $62 \mathrm{db}$ 平均損火失で, これが術後 (O) に 44db に改善され， air-bone gap る相当縮少されている。

症例 7 (図6).

奇形：細吵状正円空

手術所見では両耳共鼓室硬化症であつて，硬化組織が 両耳共砧骨，桘骨和よび鐙骨周边に広く発生し耳小骨の 可動性が失われていた，左耳では奇形なく，耳小骨連鎖 は保たれていたが，右耳では㚲骨長脚が炎症のため消失 していた.

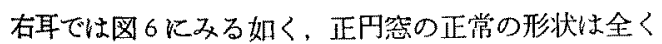
失われており，極めて細い細傹状となつて存在し，その 奥にはたして密が存在するか否かは確め難かつた，秥骨 と桘骨を除去し硬化組織を清掃してみると，鐙骨の可秐 性があつたのでろ型とした，術前聴力（○）は８1db 平 均で, 術後 (O) これが $56 \mathrm{db}$ となつている.

正円空の閉鎖佴硬化症に㧍こりらることが報告され
ているが 17) 18)，本症例小耳硬化症でなく，かつ正円空

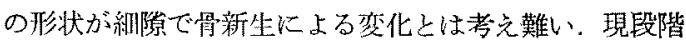
で情天性のもののよらに思われる。

\section{症例の考察}

砧鐙関節の形成は胎生第 8週に和こつてくるが，この 形成滑程に異常が扰こると先天性の関節離断がおこつて

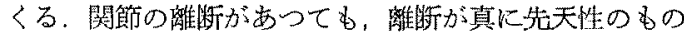
か否加の決着恃仲々つけ難いといわれている。

例えぱ炎症性の壊死が砧骨長脚に扣こつても離断がみ られる。砧骨長脚は耳小骨の他部位よりも炎症倍対する 抵抗力の弱、部位であり，慢性中耳炎の手術中に最も頻 回にみる耳小骨連鑜異常は砧鐙関節離断である，長脚は 含気胞の中に突出し，血行は耳小骨中最も末梢に位して いる，従つて急性炎症によつて容易にこの部の壊死が 和こり，急性炎症が完全に治瘛し，しかも手術をしても 炎症の痕跡を全く㑇め得なかつた場合には，砧鐙関簛離

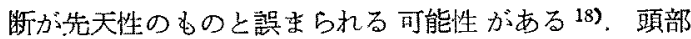

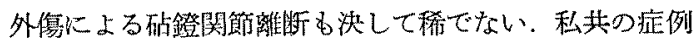
中の関節離断例では，はたして真の先天性のるのであっ たか否かについての矛問はやはり若干残つている.镫骨 についてもやはり同様な疑閂は常にここにつきまとら が，私共の極力調查した筑囲内では，これらの墨者はい ずれむ中耳炎の既往厢は否定しており，レ線像と手術侍 の耳内所見に扣いても過去に执ける何らかの炎症の痕跡 は見出し得なかつた。多小の疑問はな拓るにせ上症例

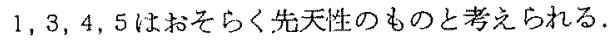

Treacher Collins Syndrome では耳小骨奇形虫雨側 性のことが多いようであるが，本諭文で取报つた単純性 の耳小骨奇形では雨侧性のこともあり1側性のこともあ る、百験例ではすべて1 側性であったが，Hough よると1側性のことが多いといら，

ある事情から外耳道異常例（閉塞例と狭小例）は自ら 繂臥し得なからたが，外耳道正常の私共の例では桘骨の 奇形はみなかつた。この所見は高原教授等 ${ }^{19)}$ によつて も観察されている。すなわち，外耳道罣常例では全例に 桘骨奇形があり，これに反して外耳道正常例では桘骨に

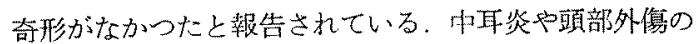
既往楚がなく，特別な奇形もなくて高度の伝音嚾㙏があ を場合には，耳硬化症と先天性の耳小骨奇形が氮和れる

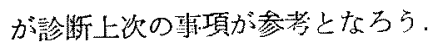

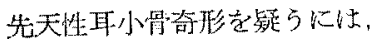

1. 1 側性の伝音難聴

2. 奻児上りの非進行性嚾渎 


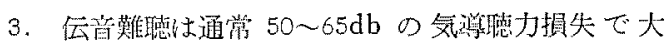
体水平型。

4. 骨獎低下があつても Carhart's notch 学示さぬ こと斿多い.

5.广找，外耳身体の他部位儿奇形也発育異常があ れぱ鼓室奇形（耳小骨奇形孔含导）の可能性がよ り強くなる。

\section{結語}

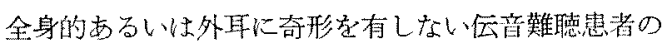
手術例中に，先天性と思われる耳小骨奇形6 例々維隚状 正円空1例を見出し，杂机らの所見々手術成維を報告し た，同时に従来の諸報告にみられた同様の患者の耳小骨 奇形と比較刘䀡し考察学加总た。

自䥒した耳小骨奇形には桘骨奇形はなく，すべて鐙骨 や炶骨の奇形であつて，その中で砧骨短脚の ankylosis 2 例を見たが，これらは奇形として稀な部類に属寸る。 手術的治療面では通常耳に対する楛室成形術の手挍がそ のまま適用される，事実私其の症例はすべてかなりの聴 力改善がみられた。

\section{文献}

1)大和田健次郎，西端八郎：聼力增進手衔を在つ た，耳小骨奇形伴克る Dystosis mandibulofacialis の1 例. 耳院科 29:1011, 昭 32.2) 中村四郎, 村上 嘉彦，鶴町昌也：両側萿室小骨の奇形を伴つた Treacher Collins' Syndrome の1 例。正㬋科, 32:957, 昭 $35 . \quad 3)$ Henner, R., and Buckingham, R.A.: The Reconstruction and Surgical Treatment of Congenital Ossicular Defects. Laryngoscope 66 : 526, 1956. 4) Henner, R.: Congenital Middle Ear Malformations. Arch. Otolaryng. 71 : 454, 1960. 5) Tolan, J.F., and Wilson, H.L.: Anomalies of the Middle Ear. Arch. Otolaryng. 68: 384, 1958. 6) Hough, J.V.D.: Malformations and Anatomical Variations Seen in the Middle Ear During the
Operation for Mobilization of the Stapes. Laryngoscope 68:1337, 1958. 7) House, H.P., House, W.F., and Hildyard, V.H.: Congenital Stapes Footplate Fixation. Laryngoscope 68: 1389, 1958. 8) Hough, J.V.D.: Congenital Malformations of the Middle Ear. Arch. Otolarylng. 78: 335, 1963. 9) Schuknecht, H. and Trupiano, S.: Some Interesting Middle Ear Problem. Laryngoscope 67: 395, 1957. 10）高原僦夫，森 哲之，中川嘉人，奥 野保夫：両側先天性中耳奇形，特飞鐙骨奇形 11 症例 について。 日兮舅，65：1033，昭 37. 11) Caparosa, R.T., and Klassen, D.: Congenital Anomalies of the Stapes and Facial Nerve. Arch. Otolaryng. 83：420，1966. 12）中村四郎, 山藤 勇: Stapes Mobilization（鐙骨可勤化手術）と，その術中 にみられた鼓空小骨の奇形。其晚科，30：769，昭 33. 13）中村四郎，山藤 票：先天性内耳空欠損症例につ いて，日聚，68：1416，昭 40. 14）Tabor, J.R.: Absence of the Oval Window. A Case Report. Arch. Otolaryng. 74:515, 1961. 15) Pou, J.W.: Congenital Absence of the Oval Window. Laryngoscope 73: 384, 1963. 16) Fernández, A.O., and Ronis, M.L: Congenital Absence of the Oval Window. Laryngoscope $74: 186,1964$. 17) Lindsay, J.R. and Hemenway, W.G.: Occlusion of the Round Window by Otosclerosis. Trans. Amer. Acad. of Ophthal. Otolaryng., June, 1954, cit. by Hough. ${ }^{6)}$ 18) Schuknecht, H.F. and Davison, R.C.: Deafness and Vertigo from Head Injury. Arch. Otolaryng. 63: 513, 1956.

（原程到着=昭和 42.3 .20 日） 